\title{
MODEL PEMBELAJARAN PKn INTEGRATIF BERBASIS TEMA KEBERAGAMAN KARAKTER INDIVIDU DI SEKOLAH DASAR
}

\author{
Ilham \\ STKIP YAPIS Dompu \\ Email: Ilhamtarbiyah@gmail.com
}

\begin{abstract}
Abstrak:
Integrasi ilmu merupakan suatu kerja berat, tetapi setidaknya usaha ini harus berkesinambungan dilakukan dengan tanpa kenal lelah, sehingga dapat memutus rantai dikotomi ilmu yang selama ini terjadi. Upaya-upaya ilmiah meski senantiasa dilakukan dalam Islam dan menjadi signifikan dengan aplikasi yang tepat, salah satunya melalui proses pembelajaran PKn. Belajar tentang Pendidikan Kewarganegaraan (PKn) pada dasarnya adalah belajar tentang keindonesiaan, belajar untuk menjadi manusia yang berkepribadian Indonesia, membangun rasa kebangsaan, dan mencintai tanah air Indonesia. Oleh karena itu, seorang sarjana atau profesional sebagai bagian dari masyarakat Indonesia yang terdidik perlu memahami tentang Indonesia, memiliki kepribadian Indonesia, memiliki rasa kebangsaan Indonesia, dan mencintai tanah air Indonesia. Pembelajaran tematik PKn Integratif dengan subtema Keberagaman karakter induvidu disebukan dalam Al-Qur'an surat Hujurat ayat 13 yang membahas pentingnya saling menghargai dan menerima karakter orang lain (keberagaman karakter induvidu), tidak berbangga diri dan tidak merendahkan orang lain dari perbadaan tersebut.
\end{abstract}

Kata Kunci: Pembelajaran PKn, Integrasi Ilmu, Karakter

\section{PENDAHULUAN}

$\mathrm{P}$ endidikan nasional berfungsi mengembangkan kemampuan dan membentuk watak serta peradaban bangsa yang bermartabat dalam rangka mencerdaskan kehidupan bangsa, bertujuan untuk berkembangnya potensi peserta didik agar menjadi manusia yang beriman dan bertaqwa kepada Tuhan Yang Maha Esa, berakhlak mulia, sehat, berilmu, cakap, kreatif, mandiri, dan menjadi warga negara yang demokratis serta bertanggung jawab. Jika mengacu pada fungsi dan tujuan pendidikan nasional tersebut jelas sekali bahwa peran nilai -nilai agama menjadi sangat penting dalam setiap proses pendidikan yang terjadi di sekolah. Karena terbentuknya manusia yang beriman dan bertaqwa serta berakhlak mulia tidak mungkin terbentuk tanpa peran dari Agama. Peningkatan iman dan taqwa melalui mata pelajaran dilakukan oleh guru 
yaitu dengan cara mengkaitkan nilai-nilai Imtaq dan Iptek dalam pembelajaran tanpa mengubah kurikulum yang sudah ada. Keberhasilan siswa dalam belajar yang dapat meningkatkan Imtaq sangat dipengaruhi oleh kondisi internal siswa maupun faktor eksternal siswa (Isnaeni, 2016). Salah satu faktor eksternal yang ikut berpengaruh atas keberhasilan siswa dalam memahami suatu topik pembelajaran yang berasal dari guru adalah kemampuan guru dalam mengintegrasikan antara pembelajran umum (Tematik) dengan Pembelajaraaan Agama. sehingga nilai -nilai Imtaq bisa mewarnai dalam pembelajaran tersebut. Salah satu komponen yang secara langsung berkaitan dengan proses belajar mengajar di sekolah adalah keterpaduan materi. Masalah inilah yang akan diangkat dan dikembangkan dalam tulisan ini.

Keterpaduan materi yang dimaksud di sini adalah keterpaduan antara materi PKn dengan Pendidikan Agama Islam. Perlu diketahui bahwa dalam PKn terdapat banyak sekali materi yang memerlukan penjelasanpenjelasan yang berkaitan dengan Pendidikan Agama Islam. Untuk itulah maka sebagai guru PKn (Tematik) dituntut memperluas wawasan pengetahuan lain selain materi PKn yang dalam hal ini materi Agama Islam. Masalahnya adalah mampukah para pendidik terutama guru PKn mengaitkan materi PKn dengan mata pelajaran Pendidikan Agama Islam, dan guru mata pelajaran lain (yang beragama Islam) mengaitkannya dengan pendidikan agama Islam. Berdasarkan uraian dia atas, penulis mengangkat tentang mengintegrasikan pembelajaran PKn Tematik dengan Pendidikan Agama Islam dengan sub tema keberagaman karakter induvidu. Tujuannya adalah agar siswa mampu menerima dan menghargai keberagaman karakter dari setiap temannya.

\section{TINJAUAN TEORITIS}

\section{Pembelajaran PKn Integratif}

Belajar tentang Pendidikan Kewarganegaraan (PKn) pada dasarnya adalah belajar tentang ke-Indonesiaan, belajar untuk menjadi manusia yang berkepribadian Indonesia, membangun rasa kebangsaan, dan mencintai tanah air Indonesia. Oleh karena itu, seorang sarjana atau profesional sebagai bagian dari masyarakat Indonesia yang terdidik perlu memahami tentang Indonesia, memiliki kepribadian Indonesia, memiliki rasa kebangsaan Indonesia, dan mencintai tanah air Indonesia. Dengan demikian, ia menjadi warga negara yang baik dan terdidik (smart and goodcitizen) dalam kehidupan masyarakat, bangsa, dan negara yang demokratis (Kemenristek, 2016). PKn merupakan salah satu mata 
pelajaran yang sangat penting untuk diajarkan pada jenjang sekolah dasar. Ruminiati menyatakan bahwa pelajaran PKn merupakan salah satu pelajaran yang berkaitan langsung dengan kehidupan masyarakat dan cenderung pada pendidikan afektif (Mujtahidin, 2018). Tetapi di dalam pelaksanaan pembelajaran, tidak sedikit yang salah menafsirkan bahwa pkn dengan PKn merupakan hal yang sama. Padahal keduanya memiliki definisi dan fungsi yang berbeda dalam pembelajaran.

Secara bahasa, istilah "Civic Education" diterjemahkan ke dalam bahasa Indonesia menjadi Pendidikan Kewargaan dan menjadi Pendidikan Kewarganegaraan. Istilah "Pendidikan Kewargaan" diwakili oleh Azra dan Tim ICCE (Indonesia Center for Civic Education) dari Universitas Islam Negri (UIN) Jakarta, sebagai pengembang Civic Education pertama di perguruan tinggi (Firman, 2018). Menurit John J. Cogan (1999) mengartikan civic education sebagai " the foundation course work in school designed to their adult lives". Civic education adalah suatu mata pelajaran dasar di sekolah yang di rancang untuk mempersiapkan warga negara muda, agar kelak setelah dewasa dapat berperan aktif dalam masyarkat. David Kerr (1999) menyatakan :Citizenship education adalah sebagai proses pendidikan dalam rangka menyiapkan warga muda akan hak-hak, peran dan tanggung jawabnya sebagai warga negara, sedangkan civics education adalah citizenship education yang dilakukan melalui sekolah (Winano, 2014).

Berdasarkan pendapat di atas dapat disimpulkan bahwa civic education dimaksudkan sebagai pendidikan kewarganegaraan dalam arti sempit atau khusus, sedangkan citizenship education dimaksudkan sebagai pendidikan kewarganegaraan dalam arti luas. Dengan demikian, istilah pendidikan kewarganegaraan (bahasa Indonesia) sesungguhnya mencakup dua pengertian dalam kosa kata bahasa Inggris yaitu civic education dan citizenship education yang keduanya memiliki cakupan makna berbeda. Kosa kata bahasa Indonesia ternyata belum mampu mewakili dua pengertian tersebut. Untuk konteks bahasa Indonesia dan untuk membedakannya istilah citizenship education diterjemahkan dan ditulis "pendidikan kewarganegaraan" (menggunakan huruf kecil di awal), sedangkan istilah civic education diterjemahkan dan ditulis "Pendidikan Kewarganegaraan" (menggunakan huruf besar di awal) (Udin Winaputra, 2001). Dengan demikian istilah pendidikan kewarganegaraan (pkn) meliputi pula di dalamnya Pendidikan Kewarganegaraan (PKn). Selain istilah Pendidiukan Kewarganegaraan sebagai terjemahan dari civic education, sebagian pakar menggunakan istilah Pendidikan 
Kewarganegaraan (Azra, 2000: Tilar, 2007) yang menurutnya lebih luas makna dan cakupannya bukan sekedar hubungan antara warga negara dengan negara, tetapi juga warga dengan warga lain atau komunitas lain diluar negara.

Secara terminologis, Pendidikan Kewarganegaraan (PKn) di Indonesia diartikan sebagai pendidikan politik yang fokus materinya adalah peranan warga negara dalam kehidupan bernegara yang kesemuanya itu di proses dalam rangka untuk membina peranan tersebut sesuai dengan ketentuan pancasila dan UUD 1945 agar menjadi warga neragara yang dapat di andalkan oleh bangsa dan negara (Cholisin, 2000). Namun Somantri (2001) mendefinikan Pendidikan Kewarganegaraan yang kiranyab cocok dengan Indonesia adalah sebagai program pendidikan yang berintikan demokrasi politik yang di perluas dengan sumber-sumber pengaetahuan lainnya, pengaruh positif dari pendidikan sekolah, masyarakat dan orang tua yang kesemua itu di proses guna melatih para siswa untuk berpikir kritis, analitis, bersikap dan bertindak demokratis yang berdasarkan pancasila dan UUD 1945. Winataputra (2005) mengartikan Pendidikan Kewarganegaraan sebagai suatu bidang kajian yang mempunyai objek telaah kebajikan dan budaya kewarganegaraan, menggunakan disiplin ilmu pendidikan dan ilmu politik sebagai kerangka kerja keilmuan pokok serta displin ilmu lain yang relevan, yang secara koheren, diorganisasikan dalam bentuk program kurikuler kewarganegaraan, aktivitas sosial-kultural kewarganegaraan, dan kajian ilmiah kewarganegaraan.

Komponen pembelajaran dalam PKn secara garis besar terdiri atas pengetahuan, sikap dan keterampilan yang harus dipelajari siswa dalam rangka mencapai kompetensi yang telah ditentukan (Winano, 2014). Secara terperinci materi pembelajaran terdiri atas materi yang bersifat pengetahuan (fakta, konsep, preposisi, prinsip, teori) materi bersifat keterampilan ( tata cara, prosedur) dan materi yang bersifat nilai. Ketiga komponen PKn berkaitan erat dengan sesama pembentukan pribadi warga negara. Warga negra yang memiliki pengetahuan dan sikap kewarganegaraan akan menjadi warga negara yang percaya diri (civic confidence), warga negara yang memilki pengetahuan dan keterampilan kewarganegaraan akan menjadi warga negara yang mampu (civic confidence), warga negara yang memiliki sikap dan keterampilan kewarganegaraan akan menjadi warganegara yang komitmen (civic commitment), dan pada akhirnya warganegara yang memiliki pengetahuan 
sikap dan keterampilan kewarganegraan akan menjadi warga negara yang cerdas dan baik (smart ang good citizenship).

Pendekatan integratif-interkonektif adalah pendekatan yang berusaha saling menghargai; keilmuan umum dan agama, sadar akan keterbatasan masing-masing dalam memecahkan persoalan manusia, hal ini akan melahirkan sebuah kerjasama, setidaknya saling memahami pendekatan (approach) dan metode berpikir (procces andprocedure) antara dua keilmuan tersebut (Hidayat, 2014). Integrasi ilmu merupakan suatu kerja berat, tetapi setidaknya usaha ini harus berkesinambungan dilakukan dengan tanpa kenal lelah, sehingga dapat memutus rantai dikotomi ilmu yang selama ini terjadi. Upaya-upaya ilmiah meski senantiasa dilakukan dalam Islam dan menjadi signifikan dengan aplikasi yang tepat, salah satunya melalui proses pembelajaran PKn (Mutma'inah, 2017).

Integrasi dapat dilakukan dengan salah satu dari beberapa pendekatan, intradisipliner, multidisipliner, interdisipliner, dan transdisipliner. Integrasi Intradisipliner yaitu mengintegrasikan kompetensi-kompetensi sikap, pengetahuan dan keterampilan menjadi satu kesatuan utuh pada setiap mata pelajaran. Pendekatan ini dilakukan dengan merumuskan keempat kelompok kompetensi dasar. Integrasi multidisipliner dan interdisipliner dilakukan dengan membuat berbagai mata pelajaran yang diajarkan pada jenjang Madrasah Ibtidaiyah saling berkaitan satu sama lain agar salingmemperkuat, menghindari tumpang tindih dan dapat menjaga keselarasan setiap mata pelajaran. Integrasi multidisipliner dilakukan tanpa menggabungkan kompetensi dasar setiap mata pelajaran, sedangkan integrasi interdisipliner dilakukan dengan menggabungkan kompetensi-kompetensi dasar dari beberapa mata pelajaran menjadi satu. Integrasi transdisipliner yaitu dengan mengaitkan berbagai mata pelajaran yang ada dengan permasalahanpermasalahan yang dijumpai di sekitarnya, sehingga pembelajaran menjadi kontekstual.

Peran pendidikanagama dalam membangun karakter atau akhlak akan lebih optimal pada masa mendatang jika ia mendapat dukungan mata pelajaran pendidikan kewarganegaraan ( $\mathrm{PKn}$ ). Bahkan bisa dikatakan dalam konteks pendidikan karakter kita tidak dapat mengabaikan peran strategis mata pelajaran pendidikan kewarganegaraan (PKn), aatau sebelumnya amata pelajaran Pendidikan Moral Pancasila (PMP). Sebagai instrumen pendidikan karakter bangsa, mata pelajaran tersebut di berikan sejak SD sampai ke perguruan tinggi (Zabacdi, 2015). Pembelajaran tematik PKn Integratif dengan subtema Keberagaman karakter induvidu 
disebukan dalam Al-Qur'an surat Hujurat ayat 13 yang membahas pentingnya saling menghargai dan menerima karakter orang lain, tidak berbangga diri dan tidak merendahkan orang lain dari perbadaan tersebut.

\section{Konsep Keberagaman Karakter Induvidu}

1. Pengertian Keberagaman Karakter

Keragaman berasal dari kata ragam yang menurut kamus besar bahasa Indonesia (KBBI) artinya : tingkah laku, macam jenis, lagu musik : langgam, warna :corak : ragi, laras (tata bahasa). Keragaman manusia bukan berarti manusia itu bermacam-macam atau berjenis-jenis seperti halnya binatang dan tumbuhan. Manusia sebagai makhluk Tuhan tetaplah berjenis satu. Keragaman manusia dimaksudkan bahwa setiap manusia memiliki perbedaan. Perbedaan itu ada karena manusia adalah makhluk individu yang setiap individu memiliki cirri-ciri khas tersendiri. Perbedaan itu terutama ditinjau dari sifat-sifat pribadi, misalnya sikap, watak, kelakuan, temperamen, dan hasrat. Contoh, sebagai mahasiswa baru kita akan menjumpai teman-teman mahasiswa lain dengan sifat dan watak yang beragam (Dianti, 2014).

Keragaman karakteristik dapat kita temukan dalam kehidupan sehari-hari, baik keragaman sifat maupun ciri-ciri khas dari setiap orang yang kita jumpai. Jadi manusia sebagai pribadi adalah unik dan beragam. Selain makhluk individu, manusia juga makhluk sosial yang membentuk kelompok persekutuan hidup. Tiap kelompok persekutuan hidup manusia juga beragam. Masyarakat sebagai persekutuan itu berbeda dan beragam karena ada perbedaan, misalnya dalam hal ras, suku, agama, budaya, ekonomi, status sosial, jenis kelamin, daerah tempat tinggal dan lain-lain. Hal demikian adalah sebagai unsur-unsur yang membentuk keragaman dalam masyarakat. Keragaman manusia baik dalam tingkat individu dan tingkat masyarakat merupakan tingkat realitas atau kenyataan yang harus kita hadapi dan alami. Keragaman individu maupun sosial adalah implikasi dari kedudukan manusia, baik sebagai makhluk individu dan makhluk sosial. Kita sebagai individu akan berbeda dengan seseorang sebagai individu yang lain.

Menurut bahasa (etimologis) istilah karakter berasal dari bahasa Latin kharakter, kharassaein, dan kharax, dalam bahasa Yunani character dari kata charassei, yang berarti membuat tajam dan membuat dalam. Dalam bahasa Inggris character dan dalam bahasa Indonesia lazim digunakan dengan istilah karakter 
(Kurniawan, 2018). Istilah berkarakter artinya memiliki karakter, Karakter adalah watak, tabiat, akhlak, atau juga kepribadian seseorang yang terbentuk dari hasil internalisasi berbagai kebajikan yang diyakini dan mendasari ca ra pandang, berpikir, sikap, dan cara bertindak orang tersebut. Kebajikan tersebut terdiri atas sejumlah nilai, moral, dan norma seperti jujur, berani bertindak, dapat dipercaya, hormat kepada orang lain (Gunawan, 2013).

Karakter menurut pengamatan filsuf kontemporer bernama Michael Novak, merupakan "campuran kompatibel dari seluruh kebaikan yang diidentifikasi oleh tradisi religius, cerita sastra, kaum bijaksana dan kumpulan orang yang berakal sehat yang ada dalam sejarah" (Lichona, 2013). Sebagaimana yang ditunjukan Novak, tidak ada seorangpun yang memili semua kebaikan itu dan setiap orang memiliki beberapa kelemahan. Orang-orang dengan karakter yang sering di puji bisa jadi sangat berbeda antara satu dengan yang lainnya. Thomas Lichona karakter adalah terdiri dari nilai operatif, nilai dalam tindakan. Kita berproses dalam karakter kita, seiring suatu nilai menjadi suatu kebaikan, suatu disposisi batin yang dapat diandalkan untuk menanaggapi situasi dengan cara yang menurut moral itu baik.

Berdasarkan pendapat para tokoh diatas Keberagaman Karakter adalah watak, tabiat, akhlak, atau juga kepribadian seseorang yang membedakannya dengan dengan orang lain dan terbentuk dari hasil internalisasi berbagai kebajikan yang diyakini dan mendasari cara pandang, berpikir, sikap, dan cara bertindak orang tersebut. Kebajikan tersebut terdiri atas sejumlah nilai, moral, dan norma seperti jujur, berani bertindak, dapat dipercaya, hormat kepada orang lain. Hal tersebut juga senada dengan yang disebutkan oleh Aqib (2012: 40) menyebutkan bahwa berdasarkan kajian nilainilai agama, norma-norma sosial, peraturan/hukum, etika akademik, dan prinsip-prinsip HAM, telah teridentifikasi butir-butir nilai yang dikelompokkan menjadi nilai utama, yaitunilai-nilai perilaku manusia dalam hubungannya dengan Tuhan Yang Maha Esa, diri sendiri, sesama manusia, dan lingkungan serta kebangsaan. Adapun secara rincih nilai-nilai tersebut adalah:

a. Hubungannya dengan Tuhan, yaitu religius. Pikiran, perkataan, dan tindakan seseorang yang diupayakan selalu berdasarkan pada nilai-nilai Ketuhanan dan/atau ajaran agamanya. 
b. Hubungannya dengan diri sendiri, yaitu jujur, bertanggung jawab, bergaya hidup sehat, disiplin, kerja keras, percaya diri, berjiwa wirausaha, berpikir logis, kritis, kreatif, dan inovatif, mandiri, ingin tahu, cinta ilmu

c. Hubungannya dengan sesama, yaitu sadar akan hak dan kewajiban diri dan orang lain, patuh pada aturan-aturan sosial, menghargai karya dan prestasi orang lain, santun, demokratis.

d. Hubungan dengan lingkungan, yaitu peduli akan sosial dan lingkungan ditunjukkan dengan sikap dan tindakan selalu berupaya mencegah kerusakan pada lingkungan alam sekitarnya, dan mengembangkan upaya-upaya untuk memperbaiki kerusakan alam yang sudah terjadi dan selalu ingin memberi bantuan bagi orang lain dan masyarakat yang membutuhkan.

e. Nilai kebangsaan, yaitu nasionalis dan menghargai keberagaman (Dianti, 2014).

\section{Implementasi Keberagaman Karakter Anak}

Saat seorang anak sedang mengembangkan identitas dirinya yang positif, juga perlu diperkenalkan tentang keberagaman yaitu mengenai perbedaan sekaligus persamaan yang dia miliki dan dimiliki orang lain. Adanya keberagaman ini perlu ditanamkan kepada anak sikap pemahaman dan penghargaan terhadap diri sendiri dan orang lain. Selain itu, juga dibangun sebuah keyakinan bahwa keberagaman yang dihadapi bukan sebuah ancaman akan tetapi justru akan memperkaya sekaligus memberikan banyak keuntungan pada sebuah hubungan.

Ada beberapa kegiatan untuk memperkenalkan persamaan dan perbedaan pada anak. Kegiatan ini dapat membantu mereka dapat memahami beberapa hal yang menjadi persamaan sekaligus perbedaan apabila dibandingkan dengan orang lain. Hal itu dapat dilakukan dengan cara :

a. Mengajak anak untuk berbagi cerita mengenai adat dan tradisi kebudayaan bersamasama dengan teman-teman dari budaya lain.

b. Secara bergantian anak-anak diminta untuk berbagi pengalaman mengenai acara keagamaan dan perayaan agama lain.

c. Memperkenalkan persamaan dan perbedaan antara anak yang satu dengan lainnya. Ini dapat dilakukan dengan menunjukkan foto, ilustrasi, musik, film dan media yang lain untuk memperkenalkan keberagaman di antara mereka (Kusmaryani, 2018). 
Implementasi pendidikan karakter disekolah dikembangkan melalaui pengalaman belajar dan proses pembelajaran yang bermuara pada pembentukan karakter dalam diri siswa. Pendidikan karakter dalam kegiatan belajar mengajar di kelas, dilaksanakan dengan menggunakan pendekatan integrasi dalam semua mata pelajaran. Khusus mataeri pendididkana Agama Islam dan PKn (karena misinya adalah mengembangkan nilai dan sikap pengembangan karakter), harus menjadi fokus utama yang bisa menggunakan berbagai strategi/metode pendiddikan karakter. Untuk kedua mata pelahjaran tersebut, karakter di kembangkan sebagai dampak pembelajaran dan pengiring (Sulistyowati, 2012).

Selain itu, pendidikan karakter juga dikembangkan melalui kegiatansiswa secara ekstrakurikuler. Kegiatan pembinaan kesiswaan yang selama ini diselenggarakan sekolah, merupakan wadah yang potensisal untuk pendidikan karakter. Kegiatan-kegiatan tersebut dapat dilakukan dengan variasi materi yang lain. Pada intinya kegiatan-kegiatan tersebut menyentuh persoalan-persoalan yang terkait dengan sosial terutama keberagaman. Kegiatan tersebut dapat menstimulasi kepekaan dan kesadaran sosial anak tentang adanya persamaan dan perbedaan antara dirinya dan orang lain.

\section{Paradigma Integratif}

\section{Bayani}

Tafsir Surat al Hujurat [10]: Kenapa Allah Menciptakan Manusia Berbeda-Beda? Dan Apa Kemuliaan yang Sebenarnya Quran.

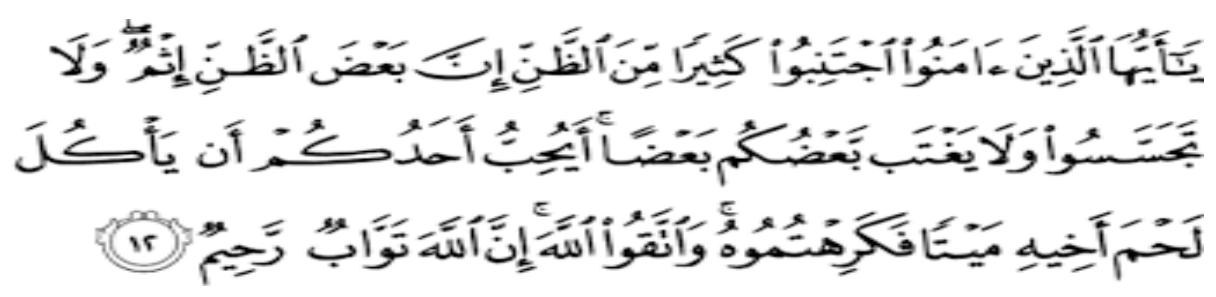

Artinya: "Hai manusia, sesungguhnya Kami menciptakan kamu dari seorang laki-laki dan seorang perempuan dan menjadikan kamu berbangsa-bangsa dan bersuku-suku supaya kamu saling mengenal. Sesungguhnya orang yang paling mulia di antara kamu di sisi Allah ialah orang yang paling bertakwa di antara kamu. Sesungguhnya Allah Maha Mengetahui lagi Maha Mengenal”. (Qs. al-Hujurat: 13).

Menurut Para ahli tafsir menyebutkan bahwa ayat di atas adalah melarang untuk berbangga diri dengan menggunakan nasab, maka maksud dari ayat "dari seorang laki-laki dan seorang 
perempuan" adalah Adam dan Hawa maknanya adalah Kami menciptakan kalian dari ayah dan ibu yang sama tanpa ada perbedaan antara yang berkulit putih dan hitam serta yang Arab dan non-Arab dan Kami jadikan kalian berbangsa-bangsa dan bersukusuku bukan untuk saling memuliakan diri kepada yang lainnya tapi agar kalian saling mengenal sehingga sebagian kalian bisa mengenal sebagaian lainnya dan dengan begitu sempurnalah urusan sosial kalian dan hubungan kalian menjadi baik, inilah tujuan kenapa Allah menjadikan kalian berbangsa-bangsa dan bersuku-suku bukan untuk membanggakan diri dengan nasab atau dengan ayah dan ibu kalian (wordpress.com, 2018).

Pendapat lain juga mengatakan bahwa maksud dari ayat "dari seorang laki-laki dan seorang perempuan" adalah laki-laki dan perempuan secara mutlak, dan ayat di atas adalah untuk menolak sikap mengutamakan diri dengan kelas-kelas secara mutlak seperti kulit putih dan hitam, Arab dan non-Arab, kaya dan miskin, majikan dan budak serta laki-laki dan perempuan, dan maknanya adalah wahai manusia sesungguhnya Kami menciptakan kalian dari laki-laki dan perempuan maka setiap orang dari kalian adalah manusia yang dilahirkan dari dua orang manusia dan kalian tidak punya perbedaan dari sisi ini, dan perbedaan bangsa-bangsa dan suku-suku di antara kalian bukanlah untuk memuliakan atau mengutamakan diri tapi agar kalian saling mengenal sehingga dengan itu sempurnalah urusan sosial kalian.

Dalam kitab al-Amtsal disebutkan bahwa yang dimaksud dengan "Kami menciptakan kamu dari seorang laki-laki dan seorang perempuan" adalah asal penciptaan dan pengembalian nasab manusia kepada Adam dan Hawa maka selama seluruh manusia berasal dari satu akar tidak diperbolehkan satu kabilah membanggakan diri atas yang lainnya dari segi nasab, dan Allah SWT menciptakan setiap kabilah dan memberikan mereka kekhususan dan tugas tertentu itu adalah untuk menjaga tatanan kehidupan sosial manusia, karena keragaman ini memancing manusia untuk saling mengenal, dan tatanan dalam masyarakat tidak akan tegak kecuali dengan pengenalan individunya, karena jika mereka memiliki model yang sama maka fitnah dan kekacauan akan menguasai masyarakat. 


\section{Burhani}

Setiap individu mempunyai karakter bawaan (heredity) dan karakter yang dipengaruhi oleh lingkungan. Karakteristik bawaan merupakan karakteristik keturunan yang dibawa sejak ia lahir baik yang berhubungan dengan faktor biologis maupun sosial psikologis (blogspot.co.id, 2016). Keyakinan masa lalu mengatakan bahwa kepribadian terbawa pembawaan dan lingkungan; merupakan dua faktor yang terbentuk karena dua faktor yang terpisah, masingmasing mempengaruhi kepribadian dan kemampuan individu bawaan dan lingkungan dengan caranya masing-masing. Namun setelah disadari bahwa apa yang dipikirkan dan dikerjakan oleh seseorang atau apa yang dirasakan oleh siapapun merupakan hasil dari perpaduan dari apa yang ada di antara faktor-faktor biologis yang diturunkan dan pengaruh lingkungan.

Perbedaan adalah sesuatu yang tidak bisa dihindari, karena setiap orang tentunya berbeda-beda. Anak kembar sekalipun pasti berbeda, dari sifat, kebiasaan, sampai kepribadiannya (klinikpelangi.com, 2017). Ketika kita hidup bermasyarakat, kita perlu mengembangkan sikap toleransi agar kita dapat menghargai orang lain yang berbeda dari kita, seperti perbedaan pendapat, perilaku, kebiasaan, karakter, dan lain-lain”, jelas Reneta Kristiani M.Psi., seorang Psikolog Klinis Anak dari Klinik Pelangi di Kota Wisata, Cibubur mengenai pengertian toleransi. Psikolog yang biasa disapa Neta ini menjelaskan bahwa setiap orang itu diciptakan Tuhan unik dengan perbedaan masing-masing. Oleh karena itu, perbedaan sebaiknya bukan menjadi sumber konflik atau suatu bahan cemoohan atau ejekan, tetapi justru dengan perbedaan itu sendiri dunia menjadi kaya akan keberagaman, indah, dan tidak membosankan". Sangat penting mengajarkan toleransi kepada anak agar anak bisa menghargai orang lain yang berbeda darinya.

Contoh Gambar Anak-anak yang hidup dalam keberagaman Karakteristik.

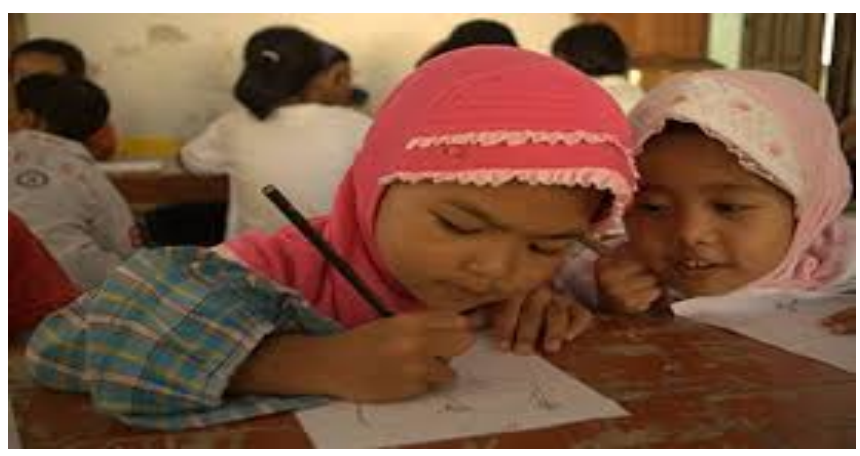




\section{Gambar Diri Sendiri.}

Kegiatan ini dilakukan dengan mengajak anak dan temantemannya untuk menggambar potret dirinya masing-masing agar bisa melihat perbedaannya dengan temannya.

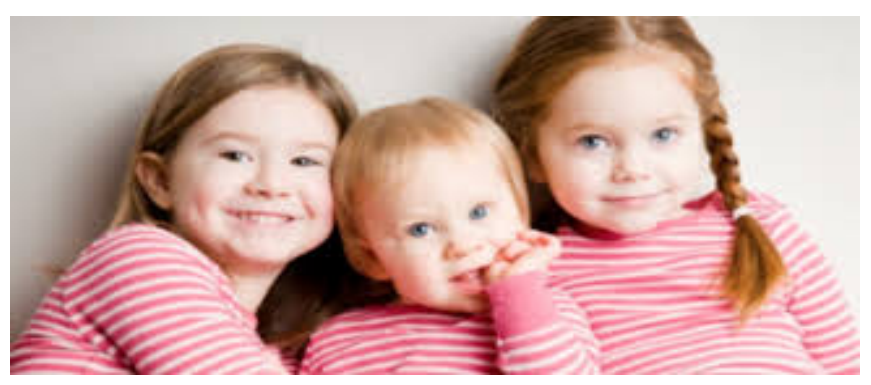

\section{Tunjukkan foto keluarga.}

Dalam kegiatan ini, anak diminta untuk menunjukkan foto keluarga kepada teman-temannya sehingga bisa melihat perbedaan dalam keluarganya sewalaupun saudara kembar.

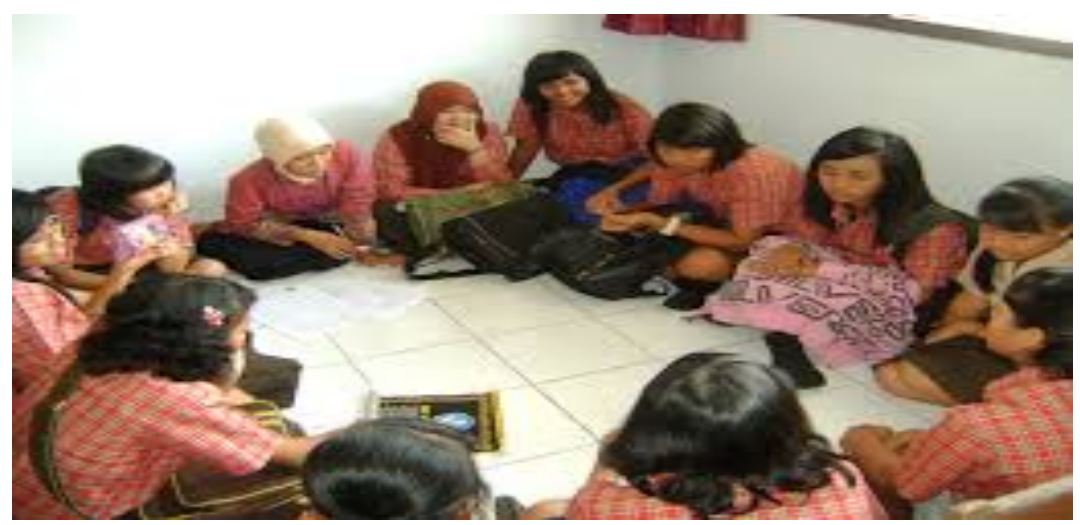

Mengakui perbedaan dan persamaan

Gambar anak-anak yang lagi musyawarah menandakan ada perbedaan pendapat maupun karakter untuk bisa menerima perbedaan pendapat temannya.

\section{Irfani}

Manfaat mempalajari keberagaman karakteristik bagi siswa adalah sebagai beriku:

a. Agar siswa mapu mengenal karakter dirinya

b. Agar siswa mampu menilai dan menyadari bahwa dirinya berbeda dengan temannya bahkan keluarganya sendiri.

c. Supaya siswa bisa membedakan karakter temanya yang satu dengan temanya yang lain. 
d. Agar siswa dapat menghargai dan mnerima segala bentuk perbedaan ketika bergaul dengan keluarga maupun teman sebaya.

e. Agar siswa dapat belajar, kerja sama dan bertyeman tampa saling menklaim atau membeda-bedakan.

f. Dengan berbagai keberagaman di sekolah, siswa akan dengan mudah memahami perbedaan dengan temanya.

g. Agar siswa dapat saling menghargai semua perbedaan dalam dirinya maupun dalam diri temannya.

\section{SIMPULAN}

Belajar tentang Pendidikan Kewarganegaraan (PKn) pada dasarnya adalah belajar tentang keindonesiaan, belajar untuk menjadi manusia yang berkepribadian Indonesia, membangun rasa kebangsaan, dan mencintai tanah air Indonesia. Oleh karena itu, seorang sarjana atau profesional sebagai bagian dari masyarakat Indonesia yang terdidik perlu memahami tentang Indonesia, memiliki kepribadian Indonesia, memiliki rasa kebangsaan Indonesia, dan mencintai tanah air Indonesia. Dengan demikian, ia menjadi warga negara yang baik dan terdidik (smart and goodcitizen) dalam kehidupan masyaraka bangsa, dan negara yang demokratis. Integrasi ilmu merupakan suatu kerja berat, tetapi setidaknya usaha ini harus berkesinambungan dilakukan dengan tanpa kenal lelah, sehingga dapat memutus rantai dikotomi ilmu yang selama ini terjadi. Upaya-upaya ilmiah meski senantiasa dilakukan dalam Islam dan menjadi signifikan dengan aplikasi yang tepat, salah satunya melalui proses pembelajaran PKn. Pembelajaran tematik PKn Integratif dengan subtema Keberagaman karakter induvidu disebukan dalam Al-Qur'an surat Hujurat ayat 13 yang membahas pentingnya saling menghargai dan menerima karakter orang lain (keberagaman karakter induvidu), tidak berbangga diri dan tidak merendahkan orang lain dari perbadaan tersebut.

\section{DAFTAR PUSTAKA}

Direktorat Jenderal Pembelajaran dan Kemahasiswaan Kementerian Riset, Teknologi, dan Pendidikan Tinggi Republik Indonesia. Cet ke 1, 2016.

Isnaeni Ida, Farida.. (2016) Model Pembelajaran Pendidkan Agama Islam Integratif, Jurnal Pendidikan Islam. Fitrah Vol. 02 No. 1 Januari - Juni.

Gunawan Heri. (2012). Pendidikan Karakter Konsep dan Implementasi. Cet 2. Bandung: Alfabeta.

http://fazilahme1410.blogspot.co.id/2016/12/keberagaman-karakteristikindividu.html. Diakses pada tanggal 07 Mei 2018. 
http://klinikpelangi.com/index.php/2017/04/01/pentingnya-mengajarkantoleransi-dan-mengenalkan-anak-tentang-keberagaman-sejakdini. Diakses pada tanggal 07 Mei 2018.

https://trianggulasiquranhadis.wordpress.com/perbedaan-bangsa-sukudalam-quran. Diakses pada tanggal 07 Mei 2018.

https://www.google.com/search?q=qur\%27an+surat+al+hujurat+ayat+11 \&source $=1 \mathrm{nms} \&$ tbm. Diakses pada tanggal 07 Mei 2018.

Lichona (2013) Educating for Character Mendidik untuk Membentuk Karakter. Cet Ke 2. Jakarta: PT Bumi Aksara.

Kurniawan., Machful Indra (2013). Integrasi Pendidikan dalam Pembelajaran pendidikan Kewarganegaraan untuk Mengembangkan Katakterdi Sekolah Dasar, Jurnal Pemikiran dan Pengembangan SD, Jilid 1, Nomor 1hlm. 37- 45, April.

Mujtahidin. (2015). Analisis Integrasi Nilai-Nilai Karakter dalam Kompetensi Dasar Mata Pelajaran PKn Kelas IV Sekolah Dasar. Jurnal pendidikan, Widyagogik. Vol. 3 No. 1 JuliDesember.

Hidayat, Muslih. (2014) Pendekatan Integratif-Interkoneksi Tinjauan Paradigma dan Implementatif dalam pembelajaran Pendididkan Agama Isalam, Jurnal pendidikan Islam, TA’DIB, Vol. XIX, No. 02, Edisi November.

Dianti, Puspa. (2014) Integrasi Pendidikan dalam Pembelajaran pendidikan Kewarganegaraan untuk Mengembangkan Katakter siswa, JPIS, Jurnal Pendidikan Ilmu Sosial, Volume 23, No. 1, Edisi Juni.

Kusmaryani,Rosita Endang. (2011). Membangun Karakter Keberagaman Pada Anak-Anak, Disampaikan dalam Seminar Nasional Pusat studi Pendidikan Anak Usia Dini "Karakter sebagai Saripati Tumbuh Kembang Anak Usia Dini", diselenggarakan oleh Pusdi Anak Usia Dini Lemlit UNY, tanggal 26 Juli.

Mutma'inah, Siti. (2017). Pendekatan Integratif: Tinjauan Paradigmatif dan Implementatif dalam Pembelajaran Fikih di Madrasah Ibtidaiyah. Jurnal Pendidikan Islam, Vol. 5 / No. 2 / JuliDesember.

Sulistyowati Enda. (2012). Implementasi Kurikulum Pendidikan Karakter. Yogyakarta: Citra Aji Parama.

Zubaedi. (2015) Desain Pendidikan Karakter Konsep dan Aplikasi dalam Lembaga Pendidikan. Cet 4. Jakarta: Kencana. 2015. 